\title{
AI 的画像解析手法による鉱物資源探査
}

\section{Mineral Resources Exploration Using AI}

\section{1.はじめに}

資源探査にリモートセンシング画像を利用する場 合，現在でも一般的な方法は，引き伸ばされた写真を 空中写真判読の要領で，地質専門家が専門知識に照ら し合わせて目で見て解析する方法である。これを写真 の目視判読という。このことは，ディジタル处理手法 がまだ一般に普及していないことの反映でもある。目 視判読は，様々な専門知識が容易に解析結果に反映さ れ易い半面, 時間がかかり, 大量処理には向かない上, 結果の主観性（非再現性）が強く，計測データとして のリモートセンシング画像を扱いにくい。これに対し て，計算機によるディジタル処理手法は，デー夕の入 手と操作にまだ難点がある。ディジタル処理そのもの も，各種統計処理や，放送用映像処理の転用，あるい は文字処理技術等の，概して単純な，あるいは組合わ せに自由度の少ない処理が多い。そのため，複雑で変 化に富む地表解析に応用できるほどの厳密さには程遠 いのが現状である。

衛星リモートセンシング画像の応用開発に当たって は，地形抽出や線状特徵抽出等の限定された目的を実 現する補助手段としてディジタル解析が使われている に過ぎない。この目的は，地質学的な資源探查応用へ の，補助的で間接的な初歩的一段階に過ぎないことが 多い。構造や，分光特徵の処理結果が得られても，さ らに専門家による次の段階の判読が不可欠であるた め，限定されたものとなっている。従って，実用に供 する立場で言之ば，ディジタル処理手法が補助的であ る上に，処理結果も補助的に利用されることにしかな らない。この結果，リモートセンシング技術の有効性 に対する疑義は数多い。これらの疑義に答え，問題解

*通産省工業技術院地質調查所

「写真測量とリモートセンシング」Vol. 30,No. 4, 1991
古宇田亮一* Ryoichi KOUDA

決を図るには，次のような方法がある。

第一に，リモートセンシングデー夕を物理的，又は， 化学的計測データとして，その精度を向上させること が重要である。これには，空間・分光分解能における センサ性能の向上が効果的である。現状のリモートセ ンシングデータに対しても精密科学的処理技術として の画像処理的アプローチを図ることもできよう。これ には, 室内と野外の計測実験值による比較も重要であ る。しかし，現状の空間・分光分解能では限界がある。

第二に, リモートセンシング・データの画像処理で は, 従来のような, 柔軟性に乏しい補助的処理手法だ けでなく，専門家の知識による複雑な判断過程を画像 処理に組み込むアプローチが考えられよう。知識処理 による画像解析へのアプローチをここでは, AI 的画像 解析手法と呼ぶことにする。AI 的画像解析手法では, 必ずしも新しい要素技術だけが技術開発上の目的では ない。従来からある要素技術の自由な組合わせで専門 知識による解析に比較できるシステム化も重要な開発 目的である。むしろ, 要素技術の目新しさと共に, 実 用上効果的な解析結果を実現する自由度の高さが, AI 的画像解析手法に本質的であると言えよう。しかし， ここで定義した $\mathrm{AI}$ 的画像解析手法の事例は少ない。

$\mathrm{AI}$ 的画像解析手法はまだ新しい分野であるが, 将来 に期待できる発展性を持つと思われるので，鉱物資源 探查におけるいくつかの適用事例をご紹介し, 問題点 と今後の課題を展望することにしよう。

\section{2. 鉱物資源探査における画像解析の諸問 題}

リモートセンシング画像の鉱物資源探査における応 用は, まず写真地質学的手法, 即ち画像判読として発 展してきた。画像判読では, 画像中に表れる個々の地 質学的，あるいは地形学的要素に注目し，これまでに 蓄積された知識を基に，各要素の特徵を画像中に見い だして画像を区分したり，特定の要素を画像から抽出 
する。例えば, 地表の色の微妙な差異, 河川系の形態 (網状 - 樹状 - 平行状 - 環状 - 菱形状等), 山稜 - 渓谷 の断面形態 (緩・急の度合等 $)$, 岩石の硬さ, 地表のテ クスチャ (滑らかさ・粗さ等), 層理面・溶岩流等の地 表と交差する線的構造, 断層等の断裂系の示す線的構 造, 植生の発達状況等を全て勘案して画像上の地表を 区分し, 岩相推定や構造 (応力場) 解析を進める。岩 相は, 岩石のまとまった特徵のことで, 化学成分が似 ているとか, 表面構造が似ている, 同じ堆積構造を持 つ等の似た性質により, 対比できる（代表的名称で呼 べる）岩石単位のことである。同じような岩相には,

同じような種類の鉱物資源が期待できることがある。 応力場は, 地層が受ける力学的場のことで, 断裂系の 理論的解析と整合性, 応力の方向や大きさ，原因等を 推定するために解析される。断裂系と断裂を充垻する 鉱脈とは密接な関係がある。

画像判読における個々の情報要素は必ずしも独立し たものではなく, 最終的には, 物理化学的物性を示す 分光情報と力学的物性を示す構造情報に分解できる。

しかし, 単純な分光情報と構造情報さ之得られるなら ば, 判読可能というわけではない。判読するためには, 適当な広がりをもつ画素群の領域的特性を地質学的・ 地形学的事象に結び付けるような分光情報と構造情報 の自由な組合わせが必要である。これは, 十分, 知識 工学の対象とすることができ, 例えば, 現象論的に結 果を得るには, 二ューラル・ネットによる分類・抽出 処理が有効である。

分光情報は対象の物理化学的特徴を示唆してくれる ので，例えば，岩石区と植生区の区分のような単純な 区分には有効である。現状のリモートセンシング情報 は分光範囲と分光分解能が共に限定的であるので, 同 一岩石区が似たような植生分布を持つとか，特に強い 粘土化変質があるとか, 鉄酸化帯が地表に表れている 等の場合に限定的に使われるだけである。これは,ディ ジタル処理の対象となり得る。高精度の空間分解能で 分光範囲と分光分解能が増せば，更に，どのような種 類の粘土鉱物をどのくらいの割合で含むかとか, 石灰 岩か珪酸塩岩か, 珪酸分がどの程度か等のことが判明 する。これによって, 岩石種が推定でき, 資源に関係 する粘土変質帯や珪化帯の分布が特定できる。しかし, これらは岩石が露出していることが必須の条件であ る。この情報は資源予測上不可欠で有用な情報となり うる。しかし, 現状のせいぜい $10 \mathrm{~m}$ 程度の空間分解能
では，分光分解能を上げても地質物性の分離が難しい ので, 依然, 将来の課題として残る。

一方, 構造情報は, 地表付近の地形的構造特徵を示 すだけでなく、リモートセンシング画像の特徵である 広域観察を生かして, 広域的に現れた地下の地質学的 情報ももたらしてくれる。構造情報は, 広域的応力場 の解析に欠かせない重要な情報であり, 地下構造の推 定は地下資源の探査に大きく貢献できる。しかし，地 表から断裂系を特定するにあたり，単純にエッジや線 構造を抽出するだけでは，本当に断裂系なのか，断裂 系以外かが自明ではない。線状の特徵から地質学的意 味を明らかにするには, 写真地質学的判定を必要とす る。線状特徴の内容の判断基準の一つとして, 画素群 の領域的性質, 例えばテクスチャを比較することが有 効である。

テクスチャはまた，岩相情報を与えてくれるので， 侵食の度合や線状特徵の分布等により, 分光情報によ る岩相分類とは異なる手段を与える。地球表面で岩石 そのものが直接観察できることは必ずしも多くない。 地表は植生や細粒の砂・土䁃に被われ, 又は, 風化表 面で岩石内部の物理化学的性質が隠れることが多い。 テクスチャはリモートセンシング画像から岩相を推定 するための主要な方法である。しかし，どのようなテ クスチャ量がどのような岩相に対応するかという，詳 しく多面的な地質学的解析が少ない。リモートセンシ ング画像の一シーン内におけるテクスチャの示す岩相 のパラメー夕は，そのシーン内だけに限定される例が 多い。他のシーンで使われたパラメータがそのままで は使いにくいため, 単純に画像処理のみに委せること ができない。更に, 一シーン内のテクスチャ特徴は多 数あり, 変化に富む。従来の目視判読では単純化した 限定的な判読しかできず, 定量的で全面的なテクス チャ解析には至らないことが多かった。これは, 既存 のリモートセンシング画像情報すら十分には利用され ていないことも意味している。

以上の問題点を解決するため $\mathrm{AI}$ 的画像解析手法が 使われ始めることは，画像処理に知識を組み合せなけ れば実用的結果が得られないという実際的要請による ものであり，必然的な流れといえるであろう。

\section{3. 資源探査のための $\mathrm{AI}$ 的画像解析手法 による解析例}

Masuda et al. $(1990)^{1)}$ は，DSDA 線抽出オペレー夕 


\begin{tabular}{|c|c|c|}
\hline knowledge of photogeologists & $\begin{array}{c}\text { included } \\
\text { or not }\end{array}$ & $\begin{array}{l}\text { how to incorporate } \\
\text { into expert system }\end{array}$ \\
\hline $\begin{array}{l}\text { 1. knowledge about under- } \\
\text { standing the outline of. } \\
\text { surveyed region. } \\
\text {.position on map } \\
\text {.rocks distributed } \\
\text {.geological structure }\end{array}$ & O & $\begin{array}{l}\text { user inputs to the system } \\
\text { the information related to the } \\
\text { surveyed region, as a label } \\
\text { image }\end{array}$ \\
\hline $\begin{array}{l}\text { 2. knowledge about grasping } \\
\text { the geographical features } \\
\text {.geographical features of } \\
\text { fault displacement } \\
\text {.classification of drainages } \\
\text { generated } \\
\text {.relation between drainage } \\
\text { pattern \& geological } \\
\text { properties } \\
\text {.relation between rock } \\
\text { categories \& amounts } \\
\text { of protrusion } \\
\text {.relation between rocks \& } \\
\text { their surfaces }\end{array}$ & 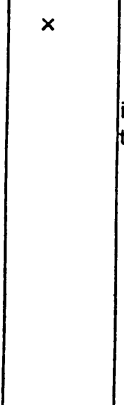 & $\begin{array}{l}\text { these are all high grade data, } \\
\text { which are considered essential } \\
\text { for proper exvaluation, however. } \\
\text { it is very difficult to establish } \\
\text { their direct relationship with the } \\
\text { image }\end{array}$ \\
\hline $\begin{array}{l}\text { 3. knowledge about extraction } \\
\text { of straight lineal structure } \\
\text {.defining the straight lineal } \\
\text { structure using the features } \\
\text { on image (such as, straight } \\
\text { linearity, difference of } \\
\text { gradation. elongation, degree } \\
\text { of clarity. etc. }\end{array}$ & 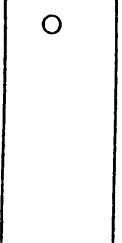 & $\begin{array}{l}\text { can be considered to be } \\
\text { mostly realized by DSDA, but. } \\
\text { since some winding and noise } \\
\text { are extracted by DSDA. it is } \\
\text { necessary to prepare rules to } \\
\text { eliminate them }\end{array}$ \\
\hline $\begin{array}{l}\text { 4. knowledge about elimination } \\
\text { of linear features } \\
\text {.linear features originating } \\
\text { from artificial objects } \\
\text {.linear features which do not } \\
\text { reflect subterranean } \\
\text { structures } \\
\text {.linear features which do } \\
\text { reflect subterranean } \\
\text { structures, but not the } \\
\text { destruction of rocks }\end{array}$ & $\Delta$ & $\begin{array}{l}\text { linear features other than } \\
\text { those which do reflect the } \\
\text { subterranean structures but } \\
\text { not the rock destruction can } \\
\text { be found out by referring to } \\
\text { the information about the } \\
\text { surveyed region, and therfore } \\
\text { can be directly incorporated } \\
\text { as they are. linear features } \\
\text { which cannot be incorporated } \\
\text { are those which cannot be } \\
\text { easily evaluated by image } \\
\text { processing }\end{array}$ \\
\hline $\begin{array}{l}\text { 5. knowledge about extraction } \\
\text { of lineament } \\
\text {. knowledge about distributing } \\
\text { positions } \\
\text {.relation with geographical } \\
\text { features } \\
\text {.relation with drainage } \\
\text {.relation with geological } \\
\text { properties } \\
\text {.relation as a geological } \\
\text { structure } \\
\text {.relation between geological } \\
\text { properties \&geological } \\
\text { structure (as general } \\
\text { knowledge) }\end{array}$ & . & $\begin{array}{l}\text { knowledge about the given } \\
\text { surveyed region. which can be } \\
\text { easily referred to. may be } \\
\text { directly incorporated as it is. } \\
\text { however. data which are } \\
\text { ambiguously defined on the } \\
\text { basis of surrounding conditions } \\
\text { or data which cannot be } \\
\text { easily evaluated from the } \\
\text { image cannot be incorperated } \\
\text { at the present stage. } \\
\text { the knowledge about unifi- } \\
\text { cation of unit lineament } \\
\text { concems unit lineament: and } \\
\text { it shall be incorporated on } \\
\text { the premise that the same } \\
\text { can be established for the } \\
\text { linear objects extracted by } \\
\text { DSDA. but the method of } \\
\text { judging straight lineal arrays } \\
\text { shall be newly studied. }\end{array}$ \\
\hline
\end{tabular}

\section{表 1 写真地質学的知識の分類 ${ }^{1)}$}

図 1 の線構造分類選択に用いる知識表現を分類表示した。xはシステムでは使われない方法である。 


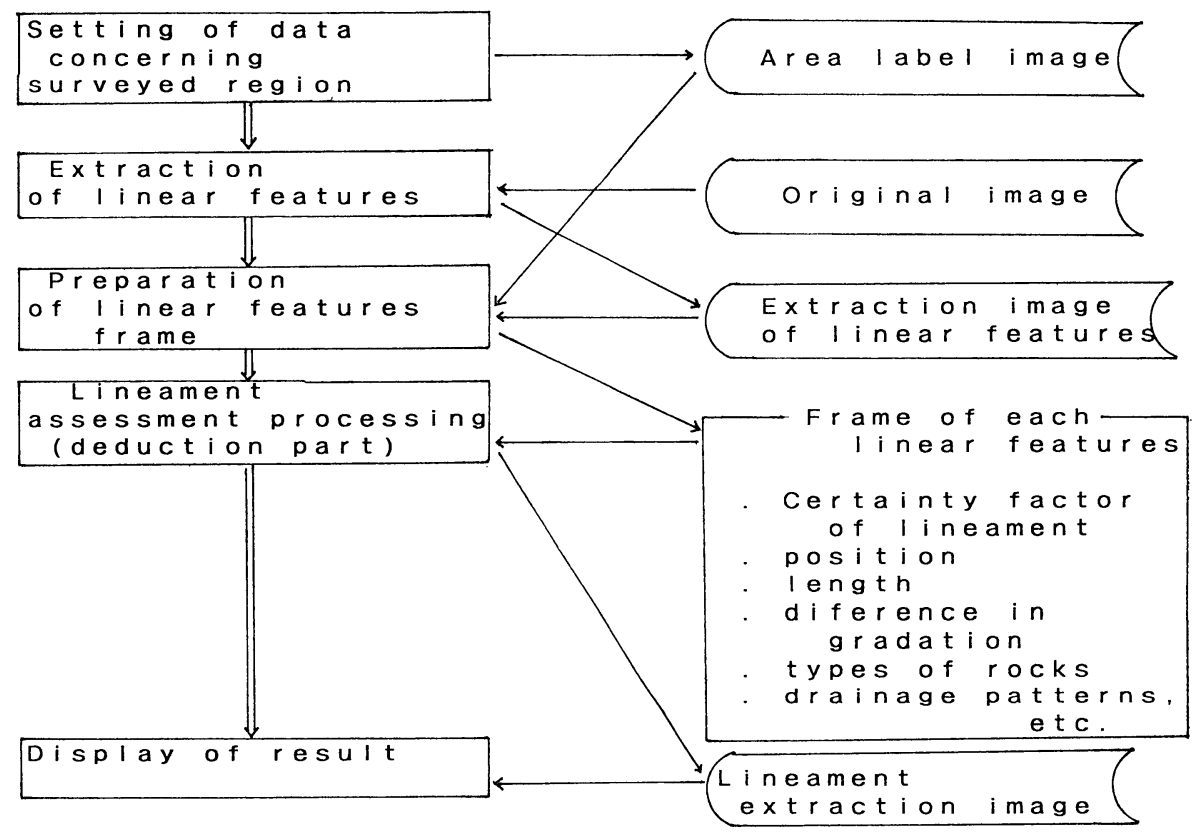

図 1 リニアメント抽出の流れ作業図 ${ }^{1)}$

対象領域の画像と画像から線構造をDSDAオペレータによって抽出した線構造の画像を用 い，予妨対象領域を区分したラベル画像によって線構造を分類選択したリニアメント図を 作成する。この時, 分類選択に表 1 の方法を用いる。

を用いて画像上の線的な構造を多量に引き出した後, その分類による取捨選択（表1）にエクスパート・シ ステム的手法（図 1) を用いて地質学的なりニアメン トを推定, 地質専門家による目視判読結果と比較した。 取捨選択の元になる線的構造の抽出の容易さは, DSDA オペレータの線抽出範囲の画素の規模によっ て決定される。この容易さは, 必ずしも目視判読の広 域的で大局的な線抽出の容易さに等しいものではない が，画素と画素の関係を検討して線的な構造の位置を 検出する点で, 微細な目視判読による線抽出（古宇田 ほか，1984（2)に類似した方法である。古宇田ほか $(1984)^{2)}$ では, 画像中のあらゆる線的構造を無差別に リニアパターンと称し, そのうち, 水域, 雲, 噴煙,

雪，人工構造物等の明らかに地質学的でない線構造を 目視判読で除き，残りの多くを地質的に意味のある構 造として，南部九州現地で調查を重ねて実証した。

Masuda et al. (1990) ${ }^{1}$ も，画像から抽出された線構造 の含まれる領域の性質から各線を評価し, 水域, 砂丘, 雲, 雪, 水河, 人工構造物の領域に含まれた線構造を 自動的に除去するという方法を用いている。線構造の 地質学的確かさに対しては次の操作を行う。軟堆積物
や新しい溶岩流領域の線構造の地質学的リニアメント の確かさを 0.5 以下に落し,複数のまとまった線構造全 体がリニアパターンを示すならば確かさを 0.7 以上 上げ，線構造の長さが30画素を超える場合は確かさを 0.3 以上に上げ，30画素以下では逆に0.3以下に落す。 この新しい方法で, 中国の含油堆積盆地の地質学的り ニアメントを126抽出し（図 2), 88 のリニアメントを 抽出した専門家による判読結果（図 3 ) と比較した。 両方とも一致するリニアメントは図 2 に示す自動抽出 結果の $53 \%$ であった。DSDA オペレータのみによる線 的構造との一致率は，20\%にすぎない(これは，選択 する前では分母が大きくなるから当然である)。この工 キスパート・システムの選択方法では, 予め対象地域 の詳しい地質・地理情報を領域データとして入力して おく必要があり, 画像だけから選択抽出したり, 画像 の一部の知識から画像全体の領域分割を行って選択抽 出することはできない。画像のみからでも目視判断の つきやすい水域, 雲, 氷河, 砂漠等は容易にマニュア ルで領域分割できるが, 軟堆積物地域か, 溶岩流が新 しいのか古いのかなどはすぐには目視判読できかね る。従って, 予め対象領域の詳しい情報が必要とされ 


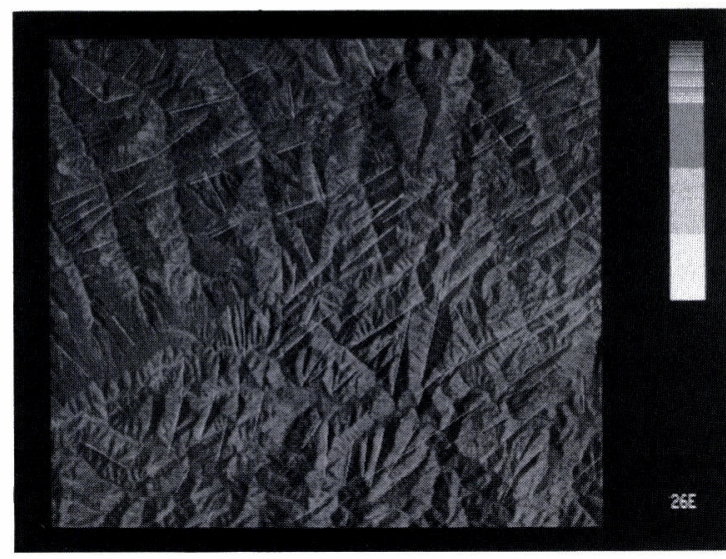

図 2 中国四川盈地における，選択抽出によるリニアメ ント自動判別結果 ${ }^{11}$

る。又, 領域分割そのものは, 自動的には行えない。

Kouda·Suwijanto $(1991)^{3)}$ は，リモートセンシング が特に必要とされている既存情報の少ない遠隔の熱帯 地域に於て, 画像から資源探査に必要な構造情報を自 動抽出する方法を開発した。対象地域の情報が少ない 場合, 画像から自動的に判断できるのは，植生に被わ れた地域か, 水域か, 雲等の画素単位のスペクトル特
徵で明らかな情報である。又, 線構造は, VanderBrug $(1976)^{4)}$ の16方向非線形線抽出オペレー夕の対象画素 を拡大して64万向以上に拡張したものを用いた。非線 形線抽出オペレータの抽出する線構造数は, オリジナ ルの VanderBrug (1976) ${ }^{4)}$ の場合極めて多数に上り (図 4)，これだけでは，どこまでが地質学的に意味の ある画像か自動的には判断できない。しかし，線構造 の密集する額域は，比較的鉱脈等の断裂系も多いとい う仮定をおけば，線密度の高い領域でのリニアパ夕ー ンを地質学的に意味のある構造と考えることができ る。更に, 鉱脈が露出し, 地形的にも複雑になってい ると仮定して, 空間分解能の高いSPOT 画像で小領域 の輝度変化の標準偏差值を求め, 以上と重ね合わせた (図 5 )。現地調査により, 以上の結果が鉱脈の分布に 関係する線構造ことを検証した。更に，この情報と， スペクトルから期待される遷移金属酸化物分布と重ね 合わせることで，鉱脈の地表露出分布域を推定し，現 地調査で含金鉱脈であることを実証した。これらの処 理は，全てディジタル処理手法で自動的に行うことが 可能であるが，予め個々の処理で何が得られるかわか らないため, 処理の組合わせを対話型で自在に変える
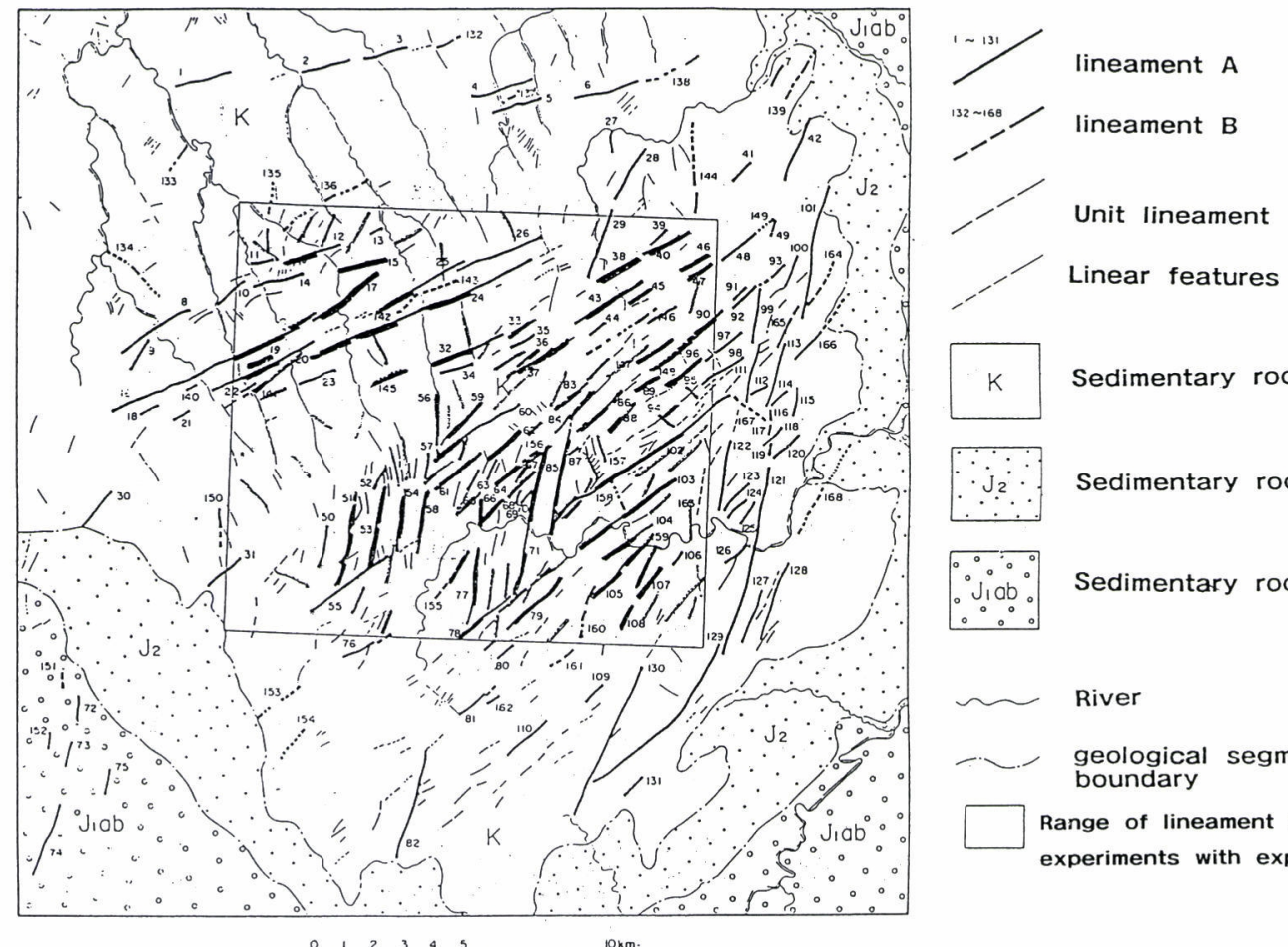

Sedimentary rocks 3

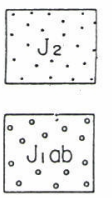

Sedimentary rocks 2

Sedimentary rocks 1

River

geological segment boundary

Range of lineament extraction experiments with expert system

図 3 中国四川盆地における，地質専門家によるリニアメント目視判読結果 ${ }^{11}$ 


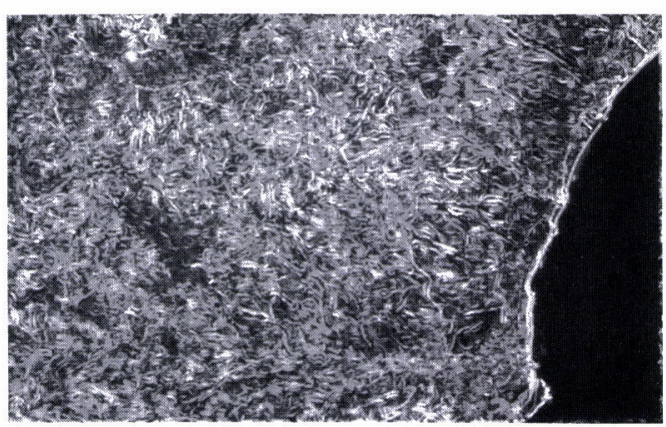

図4Vander Brugオペレータ に瀪抽出結果

(インドネシア・ロンブレン島) $)^{3)}$

必要が生じた。Tominaga·Kouda $(1990)^{5)}$ は，言語 C による処理プログラムをライブラリに組み込める市販 のエクスパート・システム (GURU) と言語Cにより 独自開発した画像処理システムを組み合せて，上述の 画像解析による探查手法のエクスパート・システム化 を試みている。

画像処理に地球物理学や地質学の知識を重ね合わせ て意味のある解析結果を得ようとする方法は，基礎的 に研究されていた (Wang, et al. (1983) ${ }^{6}$, Lee, et al. $(1987)^{7)}$, Bonham-Carter, et al. (1988) ${ }^{8)}$ 等)。Moon, et al. (1990) ${ }^{9)}$ は，画像デー夕と地質，地球物理デー夕 を重ね合わせて表示するために使われるエクスパー ト・システムのための推論機構を考察した。画像デ一 夕の範囲で得られる地質, 地球物理デー夕は, 不完全 で，精度も分散していることが多い。そこで，あいま いさを持つデータに対してべイズ統計による確率手 法, Dempster-Shafer 法の確信関数による方法, およ びFuzzy 集合による方法を比較検討した。空間的に不 完全な情報集合に対しては，ベイズ統計による方法は 困難で, Dempster-Shafer 法が処理可能であったが, その結果は，誤差の多いものであった。Shimoda et al. (1990) ${ }^{10}$ は同様の方法をネバ夕゙州のウォーカーレン地 域に適用して熱水変質帯と酸化帯を抽出している。 Moon, et al. (1990) 9)の Fuzzy 集合による方法では, 空間的に不完全な情報集合でも適切に扱えるものの䛊 差と不確実性の拡大を防ぐことはできなかった。この 課題に対して, Chung・Moon $(1990)^{10)}$ による Jacknife 型擬似変数推定法が事後情報の処理を適正化して解決 の糸口を与えるとしている。

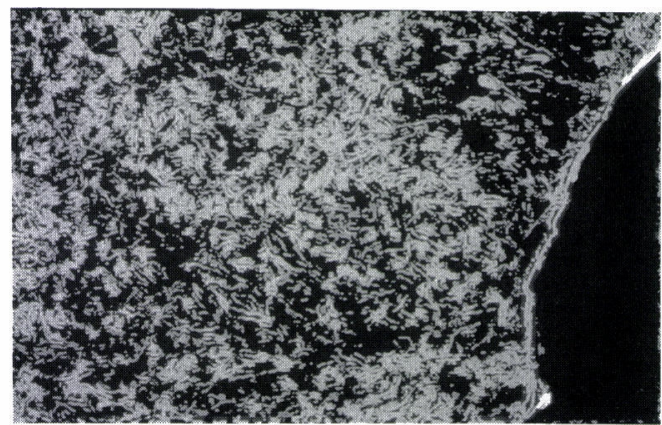

図 5 線構造, 線密度, 標準偏差画像の重ね合わせ3) 各平均值以上の二值化画像

\section{4. 今後の展望}

知識工学的手法を画像解析や画像理解に応用する試 みは多岐にわたるものの, 対象の知識が不完全で膨大 な資源探査への応用は，その困難さと相俟って，必ず しも進んだものとなってはいない。これまでに用いら れた手法も, 実際問題の解決のためには, 写真地質学 的な目視判読が大変効果的であった。目視判読のアル ゴリズムをどこまで自動化できるかが，今後の重要な 課題であろう。この問題の解明には, 解析的なアプロー チも有効であるが，二ューラルネットにより画像理解 への学習効果を高めていく方法も有効であろう。エク スパート・システムは，AI 的方法としては初歩的なも のとしても，これまでに蓄積された様々な知識処理を 組み込めるために，現在のところ，GIS と組み合せる ことで効果的になるであろうと期待されている。この ような手法が蓄積され, 先進的資源探查手法と肩を並 べられるようになれば，リモートセンシングによる鉱 物資源探査も“普通の”方法として一般に受け入れら れるようになるであろう。

\section{謝辞}

小論は, リモートセンシング技術センタ一竹内章司 主任研究員の御萀めにより執筆した。日立情報システ ムズ大谷健二部長には小論のため原画を御提供頂い た。資源観測解析センター桝田彰一調査役と原田敏夫 調査役，および，三洋テクノマリン植木俊明室長には， 小論を御閲読頂き貴重な御示唆を頂いた。以上の方々 に厚く感謝申し上げます。 


\section{参 考 文 献}

1) Masuda, S., Tokuo, T., Ichinose, T., Otani, K., and Uchi, T.: Expert system for lineament extraction from optical sensor data. In Proceedings of ISME-AI '90, Mining and Materials Processing Institute of Japan, Vol. 1, 79, 1990.

2 ）古宇田亮一, 小川克郎, 嶋崎吉彦, 佐藤壮郎, 小野雅 敏：ランドサットMSS 画像のディジタル処理による九 州南部の地形・地質構造解析, 日本リモートセンシング 学会誌, Vol. 4, pp. 321 340, 1990.

3 ) Kouda, R. and Suwijanto: Development of the method of pattern recognition for the search of nonrenewable resources in the tropical region of Indonesia. In Technical Report of Joint Research on the Enhancement and Application of the Remote Sensing Technology with ASEAN Countries, Science and Technology Agency, pp. 187 204, 1991.

4 ) VanderBrug, G.J. : Line detection in satellite imagery. IEEE Trans. Geosci. Electron. GE-14, pp. 37 43, 1976.

5 ) Tominaga, Y. and Kouda, R. : An application of expert systems for resource exploration. In Proceedings of ISME-AI '90, Mining and Materials Processing Institute of Japan, Vol. 1, pp. 199 201, 1990.

6 ) Wang, S., Elliot, D. B., Campbell, J. B., Erich, R. W., and Haralick, R. W.: Spatial resoning in remotely sensed data. IEEE Transact. Geosci. Remote Sensing, Vol. GE-21, pp. 94 101, 1987.

7 ) Lee, T., Richards, J. A., and Swain, P. H. : Probabilistic and evidential approach to multi-source data analysis, IEEE Transact. Geosci. Remote Sensing, Vol. GE-25 pp. 283 293, 1987.

8 ) Bonham-Carter, F. G., Agterberg, F. P.: Integration of Geological data sets for gold exploration in Nova Scotia, Photo. Eng. and Remote Sensing, 54, pp. 1585 1592, 1988.

9 ) Moon, W. M. and Chung, C. F. : Representation and Integration of Geological, Geophysical, and remote sensing data. In Proceedings of ISME-AI '90, Mining and Materials ProcessingInstitute of Japan, Vol. 1, pp. $162 \sim 166,1990$.

10) Shimoda, H., Fukue, K., Tokunaga, M., and Osada, T.: Extraction of the hydrothermally altered and oxidation zones using the Dempster-Shafer rule. In Proceedings of ISME-AI '90, Mining and Materials Processing Institute of Japan, Vol. 1, pp 207-210, 1990.

11) Chung, C. F. and Moon, W. M. : Combination rules of spatial geoscience date for mineral exploration. In Proceedings of ISME-AI '90, Mining and Materials Processing Institute of Japan, Vol. 1, pp. 131 141, 1990. 